УДК 338.48:656.025.2(477.64)

https://doi.org/10.52058/2708-7530-2021-9(15)-297-305

Конох Анатолій Петрович доктор педагогічних наук, професор, завідувач кафедри теорії та методики фізичної культури i спорту, Запорізький національний університет, вул. Жуковського, 66, м. Запоріжжя, 69095, тел.: (067) 752-05-54, e-mail: konoch105@ukr.net, https://orsid.org/0000-0003-4283-9317

Маковецька Наталія Валеріїна доктор педагогічних наук, професор, завідувачка кафедри туризму та готельно-ресторанної справи, Запорізький національний університет, вул. Жуковського, 66, м. Запоріжжя, 69095, тел.: (066) 337-37-12, e-mail: mail.znu.edu.ua, https://orsid.org/ 0000-0003-3735-2205

Конох Андрій Анатолійович кандидат педагогічних наук, доцент кафедри туризму та готельно-ресторанної справи, Запорізький національний університет, вул. Жуковського, 66, м. Запоріжжя, 69095, тел.: (063) 741-79-98, e-mail: mail.znu.edu.ua, https://orsid.org/0000-0001-9719-0418

\title{
ТРАНСПОРТНОЇ ІНФРАСТРУКТУРА В ТУРИСТИЧНІЙ ГАЛУЗІ ЗАПОРІЗЬКІЙ ОБЛАСТІ: СТАН ТА ПЕРСПЕКТИВИ
}

Анотація. У статті проаналізовано стан та перспективи розвитку транспортної інфраструктури туристичної галузі Запорізької області. Виявлино, що Запорізька область має великий транспортний потенціал, який може сприяти розвитку транспортної мережі, прискоренню інтеграції області в економічний простір України, а також збільшити потоки в’їздного туризму, але, в даний час стан транспортної інфраструктури туристичної галузі Запорізького регіону не можна вважати задовільним. Більшість інфраструктурних об'єктів транспорту треба визнати несучасними, занедбаними, не відповідають вимогам якості послуг туристами. Особливо, це стосується залізничного та автомобільного транспорту. Автомобільні мережі не відповідають європейським стандартам щодо багатьох показників. Проблеми на морському, річковому та повітряному видах транспорту пов'язані зі значним фізичним і моральним спрацюванням транспортних засобів. Для вирішення поставленої мети у роботі зроблено корпоративний аналіз, який дозволив надати характеристику основних проблем транспортної інфраструктури туристичної галузі запорізької області. Також був використаний діалектичний підхід до вивчення явищ і процесів транспортної інфраструктури туристичної галузі. У роботі досліджено сучасний стан транспортної інфраструктури туристичної галузі Запорізького реіону, а також проблеми та перспективи розвитку туристичної транспортної інфраструктури $\mathrm{i}$ запропоновані шляхи вирішення конкретних завдань для зміцнення позицій на туристичному ринку 
всієї транспортної інфраструктури України. Запропоновані напрями удосконалення транспортної інфраструктури в сфері туризму, які потребують значних інвестицій на відновлення існуючої, удосконалення організаційних структур управління туристичною сферою. Використання наведених пропозицій призведе до збільшення доходів, що надходять до регіонального і місцевого бюджетів і тим самим покращать рівень життя населення. Це позитивно позначиться на зростанні попиту на продукцію місцевої промисловості, збільшенні об'єктів туризму, стану транспортної та туристичної інфраструктури в регіоні, дозволить вирішувати проблеми зайнятості.

Ключові слова: транспортна інфраструктура, туристична галузь, транспортні послуги, рекреаційні ресурси, сфера туризму

Konokh Anatoliy Petrovich Doctor of Pedagogical Sciences, Professor, Head of the Department of Theory and Methods of Physical Culture and Sports, Zaporizhia National University, Zhukovsky St., 66, Zaporozhye, 69095, tel.: (067) 752-05-54, e-mail: konoch105@ukr.net, https://orsid.org/0000-0003-4283-9317

Makovetskaya Natalia Valeriina Doctor of Pedagogical Sciences, Professor, Head of the Department of Tourism and Hotel and Restaurant Affairs of Zaporizhia National University Zaporozhye, Zhukovsky St., 66, Zaporozhye, 69095, tel.: (066) 337-37-12, e-mail: mail.znu.edu.ua, https://orsid.org/ 0000-0003-3735-2205

Konokh Andriy Anatoliyovych Candidate of Pedagogical Sciences, Associate Professor of Tourism and Hotel and Restaurant Affairs of Zaporizhia National University Zaporozhye, Zhukovsky St., 66, Zaporozhye, 69095, tel.: (063) 741-79-98, e-mail: mail.znu.edu.ua, https://orsid.org/0000-0001-9719-0418

\section{TRANSPORT INFRASTRUCTURE IN THE TOURIST INDUSTRY OF ZAPORIZHZHA REGION: STATE AND PROSPECTS}

Abstract. The article analyzes the state and prospects of development of transport infrastructure of the tourist industry of Zaporozhye region. It was found that Zaporizhzhia region has a great transport potential, which can contribute to the development of the transport network, accelerate the integration of the region into the economic space of Ukraine, as well as increase inbound tourism flows, but currently the transport infrastructure of the Zaporizhzhya region can not be considered satisfactory. . Most of the infrastructural objects of transport should be considered outdated, abandoned, do not meet the requirements for the quality of services provided by tourists. This is especially true for rail and road transport. Car networks do not meet European standards for many indicators. Problems with sea, river and air transport are associated with significant physical and moral operation of vehicles. To solve this goal, a corporate analysis was made, which allowed to provide a description of the main 
problems of the transport infrastructure of the tourism industry of the Zaporozhye region. A dialectical approach to the study of the phenomena and processes of the transport infrastructure of the tourism industry was also used. The current state of the transport infrastructure of the tourist industry of Zaporizhia region, as well as problems and prospects of tourist transport infrastructure and proposed ways to solve specific problems to strengthen the position in the tourist market of the entire transport infrastructure of Ukraine. The directions of improvement of transport infrastructure in the sphere of tourism which demand considerable investments on restoration of existing, improvement of organizational structures of management of tourist sphere are offered. The use of these proposals will increase revenues to regional and local budgets and thus improve living standards. This will have a positive impact on the growth of demand for local industry products, increase in tourism facilities, the state of transport and tourist infrastructure in the region, will solve employment problems.

Keywords: transport infrastructure, tourism industry, transport services, recreational reso urces, tourism sphere

Постановка проблеми. Запорізька область - край, який має невичерпний туристичний потенціал, багатовікову історичну та культурну спадщину і входить до числа найбільш економічно розвинених областей країни. Внаслідок суспільнополітичної ситуації в країні Запорізька область отримала шанс вивести на новий рівень туристичну галузь, адже вона має величезний потенціал для розвитку туризму, і не тільки внутрішнього. До конкурентних переваг Запорізької області віносяться освічений і креативний людський капітал, потужна промисловість, та сільськогосподарське виробництво, багаті природні та рекреаційні ресурси. Використання цих переваг $\epsilon$ запорукою прискореного розвитку економіки та туристичної галузі області, які безпосередньо залежать, в першу чергу, від модернізації та розбудови транспортної інфраструктури.

Результати досліджень українських і закордонних вчених свідчать про важливу складову транспорту в розвитку туризму. Разом 3 тим, недостатні дослідження взаємозв'язку, наявності спільності і відмінності продукції туризму і транспорту, основні напрямки i завдання розвитку транспортної системи Запорізької області, які необхідно реалізовувати для задоволення потреб туристської галузі у перевезеннях туристів.

Оцінка взаємозв'язків транспортної і туристичної сфери, з урахуванням їх динаміки, функціональної організації, проблем і перспектив розвитку визначили актуальність дослідження.

Аналіз останніх досліджень i публікацій. Проблеми удосконалення транспортної інфраструктури та іiі використання в туристичній галузі знайшли своє відображення в численних публікаціях як вітчизняних (В.Ф. Кифяк [4] О.О. Любіцева [6], Е. А. Петренок [8], О.О. Фастовець [10], П.О. Яновський [12] та ін.) так і зарубіжних вчених (М.Б. Біржаков та В.I. Нікіфоров [1], М.П. Комаров [5] та ін.). Як правило, ці роботи переважно присвячені важливим 
аспектам роботи транспорту, пов'язаних 3 організацією i здійсненням перевезення туристів.

Не дивлячись на те, що цій проблемі було виділено достатньо уваги, питанням взаємодії туризму 3 транспортною системою Запорізької області недостатньо розглядалися. Дослідження транспортної інфраструктури та їх використання в туристичній сфері $€$ актуальним, як в науковому плані, так i 3 практичної точки зору.

Метою статті $\epsilon$ аналіз стану та визначення перспектив розвитку транспортної інфраструктури в туристичній галузі Запорізької області.

Виклад основного матеріалу. Розвиток i перспективи територіальної організації господарства регіону залежать від розвитку всіх елементів інфраструктури, тому на сучасному етапі розвитку економіки важливим питанням є іï ефективне функціонування.

Транспорт i транспортна інфраструктура $\epsilon$ складовими частинами туристичної галузі, а отже інфраструктури транспорту та інфраструктури туристичних підприємств. Туристична інфраструктура транспорту забезпечує перевезення туристів і складається з різних видів транспорту.

Дослідники М.Б. Біржаков, В.И. Никифоров [1], В. Ф. Кифяк [4] та ін. вважають, що пасажирський транспорт $\epsilon$ самостійною галуззю, який має задовольняти попит туристів у перевезеннях і не входить до складу туристичної індустрії.

Вчені В. Г. Гуляєв [2], I. М. Писаревський [9] та ряд інших авторів розглядають транспортне обслуговування туристів як одну з головних складових частин індустрії туризму. Це можна пояснити відсутністю єдиних критеріїв, що визначають туристичний транспорт як вид пасажирського транспорту для перевезення туристів. Переважна більшість науковців та економістів-практиків вважають транспорт невід'ємною частиною туристичної індустрії, що обслуговує туристів заздалегідь обумовленими маршрутами 3 використанням різних видів транспортних засобів.

На нашу думку, туристичний транспорт є окремим спеціалізованим видом пасажирського транспорту, який пов’язаний з обслуговуванням туристів.

Поняття транспортної інфраструктури включає в себе транспортну систему всіх видів транспорту, що працюють у сфері переміщення людей і вантажів. Вона $\epsilon$ основою транспортного комплексу регіону, сприяє формуванню транспортної мережі. Одним з головних завдань транспортної інфраструктури в туристичній сфері є створення комплексних умов для перевезення туристів та їх доступу до туристичних об'єктів. Транспортна інфраструктура туризму - це комплекс, який охоплює транспортні засоби, об'єкти, шляхи і маршрути, транспортні послуги, об’єкти сервісу і туризму на транспортних об'єктах і засобах, засоби інформації. Вона відіграє важливу роль в розвитку будь-якого регіону, тому що туристична галузь характеризується підвищеною видовою i просторовою динамічністю i потребує в своєму розвитку транспортного забезпечення. Транспортна 
туристична інфраструктура охоплює весь транспортний комплекс, вирішує завдання розвитку інфраструктури транспорту і впливає на розвиток туристичної галузі. Регіональну туристичну транспортну інфраструктуру можна розглядати як систему всіх видів транспорту з усіма їх складовими частинами та ланками, а також усіма іншими обслуговуючими частинами інфраструктури, що працюють у сфері переміщення пасажирів.

Однак, у дослідників на сьогодні немає єдиної думки щодо визначення можливостей ефективного використання транспорту і відповідної інфраструктури для потреб туристичної сфери регіону.

У Запорізькій області протягом останніх років відбулась інтенсифікація розвитку туристичної сфери. Для задоволення потреб в оздоровленні та відпочинку мешканців і гостей області на території регіону знаходиться понад 550 закладів тимчасового розміщення, серед яких: 437 баз відпочинку, 56 закладів готельного типу, 8 оздоровчих центрів та комплексів, 24 санаторнопрофілакторні заклади, 6 пансіонатів, 3 туристичні притулки, 28 дитячих таборів. Протягом останніх років область щороку відвідує 15-16 тис. осіб [13, С. 61].

Основними напрямами розвитку туризму в регіоні є історико-культурний та рекреаційно-курортний, в тому числі сільський (зелений) туризм. Історикокультурна спадщина Запорізької області є невід'ємною складовою культурного надбання України [13, С. 61].

Найбільш відвідуваними $є$ Національний заповідник «Хортиця», Національний історико-археологічний заповідник «Кам'яна Могила», Василівський історико-архітектурний музей-заповідник «Садиба Попова».

У межах прибережної смуги Азовського моря формуються і розвиваються такі курортно-рекреаційні підрайони, як Бердянський, Новопетрівський, Райнівський, Кирилівський, Строганівський, Новокостянтинівський, Приморський.

Активне зростання кількості туристів на приазовських територіях значною мірою зумовлено анексією АР Крим. Пандемія стала викликом і відкрила нові можливості для розвитку внутрішньому туризму. Чимало українців, які раніше обирали для відпусток іноземні країні, змушені були залишитися в Україні. На Приазов'я подалося чимало людей зі статками вище середніх і відповідними вимогами до відпочинку. У Приазов’я найбільше іздять жителі найближчих регіонів - Запоріжжя, Донеччини, Луганщини, Харківщини. Це пов’язано і 3 логістикою. Звідси до моря недалеко автобусом чи власною автівкою. Але, щоб привернути увагу туристів з інших областей - необхідно покращувати стан доріг, логістику добирання.

Фактично приморські райони Запорізького регіону та курортні зони на узбережжі Азовського моря, які до цього програвали конкурентну боротьбу кримським курортам, отримали можливість наростити власний економічний потенціал за рахунок розвитку туризму. Приазов'я має потужний туристичний потенціал. Але для того, аби на рівних конкурувати 3 чорноморськими i

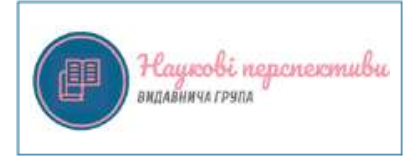


закордонними курортами, необхідно покращити імідж регіону, у тому числі екологічний та геополітичний. Залучати для туристичного розвитку інвестиції, активізувати мале та середнє підприємництво і змінити цільову аудиторію. Аби туристична галузь могла добре заробляти, треба пропонувати не лише бюджетний відпочинок, але і покращити сервіс обслуговування туристів.

Результатом цього може стати суттєве зростання доходів місцевих бюджетів приморських районів за рахунок туристичного збору.

Запорізька область має достатньо розвинену диверсифіковану транспортну систему, до якої входить мережа автомобільних та залізничних шляхів, а також об’єкти морського, річкового, авіаційного та електротранспорту, зокрема: Запорізький міський електротранспорт, Запорізький аеропорт, Запорізький річковий порт та Бердянський морський торговельний порт. Щільність залізничних колій загального користування в регіоні $\epsilon$ вищою у порівнянні 3 середньоукраїнським значенням цього показника і становить 36 км/тис. кв. км проти 34 км/тис. кв. км. Основні залізничні вузли Запорізької області: Мелітополь, Запоріжжя, Бердянськ $\quad$ [13, С. 51].

У 2021 році в м. Запоріжжі побудований КП «Міжнародний аеропорт Запоріжжя», який значно посилив конкурентні переваги Запорізького регіону на туристичному ринку південно-східного регіону України. Аеропорт зручно розташований від центру міста Запоріжжя, залізничної магістралі ХарківСімферополь та автостради Запоріжжя - Донецьк.

Провідну роль у перевезеннях пасажирів Запорізької області відіграє автомобільний транспорт, адже він $\epsilon$ найвигіднішим під час поїздок до курортних міст Приазов'я та пам'ятним місцям. Туристичні фірми використовують автобуси для відвідування туристами спортивних та культурних заходів, обслуговування ярмарків, виставок. Автомобільний транспорт можна 3 повним правом назвати транспортом загального застосування у сфері туризму, адже він доступний всім верстам населення [14].

Щільність автомобільних доріг загального користування 3 твердим покриттям Запорізької області складає 251 км на 1000 км.кв. території [13, С. 51 ]. Автомобільні дороги переважно мають незадовільний технічний стан, мостові переходи значно перевантажені транспортними потоками.

Понад 80\% доріг Запорізької області зведені понад 30 років тому і на теперішній час не відповідають вимогам сучасного автомобільного руху та технічним параметрам. При їх будівництві передбачалась інтенсивність руху до 9 тисяч автомобілів на добу та максимальна швидкість 90 км/год [11].

Слід відзначити, що за останні два роки в Запорізькій області капітально відремонтовано такі стратегічно важливі автомобільні дороги, як ЗапоріжжяДніпро (84 км), Запоріжжя-Маріуполь (224 км), Запоріжжя-Бердянськ (198 км), Запоріжжя-Мелітополь (124км), Мелітополь-Кирилівка (63 км), що надало можливість значно поліпшити автоперевезення, як вантажів так і пасажирів, зокрема, туристів до приазовських курортних міст Бердянська, Приморська та 
популярної Кирилівки.

На сьогодні однією 3 головних проблем м. Запоріжжя є реконструкція існуючих та будівництво нових мостів через річку Дніпро. На території області $\epsilon$ два мостові переходи через річку Дніпро, які розташовані в міській зоні Запоріжжя - дамба ДніпроГЕСу та мости Преображенського. Найближчі до них мостові переходи розташовані в сусідньому обласному центрі Дніпрі. Мости Преображенського, які були побудовані ще на початку 50-х років $\mathrm{XX}$ ст.. Вони не розраховані на сучасний потік транспорту, який перетинає річку Дніпро. Мости знаходяться в незадовільному стані і потребують капітального ремонту. У результаті м. Запоріжжя відчуває критичну нестачу пропускної здатності мостів Преображенського, які зв'язують центральну частину міста 3 Хортицьким районом, що знаходиться на протилежному від центру, правому березі Дніпра. Погіршує ситуацію і те, що Запоріжжя $є$ транзитним містом i через мости проходять значні потоки транзитного автотранспорту.

Зведення нового мостового переходу через Дніпро у Запоріжжі триває з 2004 року. Воно неодноразово припинялись через проблеми 3 фінансуванням. Востаннє будівельні роботи поновлювались у 2016 році, коли було досягнуто згоди про спільне фінансування робіт із державного та місцевого бюджетів. 3 початку 2021 року відновлено будівництво автотранспортної магістралі через $\mathrm{p}$. Дніпро у м. Запоріжжя, яке планується завершити у 2022 році. Загострює ситуацію й те, що дамба ДніпроГЕСу має бути перекрита для капітального ремонту найменьш як на 2-3 роки [13, С. 53].

Щодо сільських автомобільних доріг, то їх стан є незадовільний і потребує капітального ремонту. Як наслідок, на цих дорогах виникає значна кількість транспортних пригод, що призводить до загибелі і каліцта людей. На погіршення стану доріг, особливо в східних районах області, впливає рух важкої військової техніки. Для ремонту існуючої мережі автомобільних доріг необхідно щороку ремонтувати капітальним ремонтом понад 600 км доріг, поточним середнім ремонтом - до 2000 км. Проведення цих робіт потребує залучення значних фінансових ресурсів [13, С. 53]. За останні роки значно змінились умови руху на дорогах. Різке збільшення великовагових машин призвело до інтенсивного руйнування дорожнього покриття. На даний час міцність та довговічність доріг залишається основним завданням служби автодоріг області.

Принципово важливим є те, що в дорожній галузі досягнуто позитивної динаміки якісних показників завдяки застосуванню нових технологій, сучасної техніки для вдосконалення та відновлення транспортно-експлуатаційних i технічних характеристик доріг та споруд на них, підвищення якості виконаних робіт, довговічності та надійності доріг.

Незадовільний економічний стан, військові дії на сході країни, відчудження Автономної республіки Крим Російською федерацією, значно погіршило використання транспортної інфраструктури в туристичній галузі Запорізької області. Суттєві ускладнення мають туристи під час подорожі до Криму, як 
автомобільним так і авіаційним транспортом. До цих проблем слід віднести ще й такі проблеми транспортної інфраструктури і внутрішнього туризму Запорізької області як незадовільне фінансування, неудосконале законодавство, інфляція та значне зниження доходів громадян.

Для формування та подальшого розвитку туристичної галузі Запорізької області, необхідним, в першу чергу, $\epsilon$ удосконалення транспортної інфраструктури регіону, а саме: розвиток річкових та морських портів, будівництво сучасних швидкісних автомагістралей та створення вздовж них обслуговуючих комплексів для надання якісних сучасних послуг, які хочуть отримувати туристи.

Висновки. Сучасний стан транспортної інфраструктури туристичної галузі Запорізького регіону не можна вважати задовільним. Значна частина інфраструктурних об'єктів транспорту $\epsilon$ несучасні i не відповідають європейським вимогам. Проведений аналіз сучасного стану туристичного ринку свідчить, що Запорізька область має значний туристичний потенціал, достатньо розвинуту транспортну систему, що, за виконанням певних умов, дозволяє значно збільшити обсяг як внутрішнього, так і в’їздного туризму. Зростає необхідність у подальших дослідженнях щодо оптимізації транспортної інфраструктури Запорізького регіону в туристичній галузі 3 метою надання якісних i різноманітних послуг туристам.

\section{Jimepamypa:}

1. Биржаков М. Б. Индустрия туризма: перевозки. / М.Б. Биржаков, В.И. Никифоров СПб: Издательский дом «Герда». 2007. - 528 с.

2. Гуляев В. Г. Организация туристских перевозок. / В.Г. Гуляев - М.: Финансы и статистика, 2003. - $510 \mathrm{c}$.

3. Державна служба автомобільних доріг України. [Електронний ресурс]. - Режим доступу: http://www.ukravtodor.gov.ua.

4. Кифяк В. Ф. Стратегія розвитку територіальних рекреаційних систем: теорія, методологія, практика: монографія. / В.Ф. Кифяк. - Чернівці : Книги - XXI, 2010. - С. 215-217.

5. Комаров М. П. Инфраструктура регионов мира. / М.П. Комаров. - СПб.: Изд-во Михайлова В. А., 2000. - 347 с.

6. Любіцева О.О. Методика розробки турів. / О.О. Любіцева. - К. : Альтерпрес, 2003. -104 с.

7. Офіційний сайт Державної служби статистики України. [Електронний ресурс]. Режим доступу: http://ukrstat.gov.ua.

8. Петренок Е. А. Проблема монополизма на железнодорожном транспорте.

Е. А. Петренок // Вісник Дніпр. нац. ун-ту заліз. тран. імені академіка В. Лазаряна, 2011. Вип. 40. - C. 289-295.

9. Писаревський I.M. Залізниця та залізничний туризм: точки перетину.

I.M. Писаревський // Зб. наук. пр. Київ. ун-ту економіки і технологій транспорту: Серія «Економіка і управління». - К.: ДЕТУТ, 2008. Вип. 12. - С. 61-63.

10. Фастовець О. О. Розвиток транспортної системи з найдавніших часів до початку XX ст. як чинник виникнення туристичної галузі. / О.О. Фастовець // Туристично-краєзнавчі дослідження. - К.: Державне підприємство «Національна туристична організація», 2002. - С. 418-443.

11. Укравтодор. Державне агентство автомобільних доріг України. // Бюлетень доріг 2008 року. [Електронний ресурс]. - Режим доступу: www. ukravtodor.gov.ua. 
12. Яновський П.О. Пасажирські перевезення. / П.О. Яновський. - К. : НАУ, 2008. -469 с.

13. Стратегія регіонального розвитку Запорізької області на період до 2027 року. Рішення Запорізької обласної ради від 12.12.2019 № 134. 148 с. [Електронний ресурс]. Режим доступу: https: //www.minregion.gov.ua > regional-dev > strategi

14. Yukhnovskaya Y.O. The current state of transport infrastructure of the tourism industry of Ukraine. Coll. Science. Dnipro Ave. nat. University of Iron. transp named after Academician V. Lazaryan, «Problems of Transport Economics», 2018, vol. 16. pp. 76-84.

\section{References:}

1. Byrzhakov M.B. (2007) Industriya turizma: perevozki [Tourism industry: transportation]. St. Petersburg: Gerda Publishing House [in Russian].

2. Guliaev V.G. (2003) Organizatsiya turistskikh perevozok [Organization of tourist transportation]. Moscow .: Finance and Statistics [in Russian].

3. Derzhavna sluzhba avtomobilnykh dorih Ukrainy [State Service of Motor Roads of Ukraine] Access mode: http://www.ukravtodor.gov.ua. [in Ukrainian].

4. Kyfiak V.F. (2010) Stratehiia rozvytku terytorialnykh rekreatsiinykh system: teoriia, metodolohiia, praktyka: monohrafiia [Strategy for the development of territorial recreational systems: theory, methodology, practice: monograph]. Chernivtsi: Books. XXI [in Ukrainian]

5. Komarov M.P. (2000) Ynfrastruktura rehyonov myra [Infrastructure of the world]. SPb .: Izd-vo Mikhailova V.A. [in Russian].

6. Liubitseva O.O. (2003) Metodyka rozrobky turiv [Methods of tour development]. Kiev. : Альтерпрес [in Ukrainian].

7. Ofitsiinyi sait Derzhavnoi sluzhby statystyky Ukrainy [Official site of the State Statistics Service of Ukraine]. Access mode: http://ukrstat.gov.ua. [in Ukrainian].

8. Petrenok E.A. (2011) Problema monopolyzma na zheleznodorozhnom transporte [The problem of monopoly on railway transport]. Bulletin of the Dnieper. nat. University of Iron. tran. named after Academician V. Lazaryan [in Ukrainian].

9. Pysarevskyi I.M. (2008) Zaliznytsia ta zaliznychnyi turyzm: tochky peretynu [Railway and railway tourism: points of intersection]. Coll. Science. Kyiv ave. University of Economics and Transport Technologies: Series "Economics and Management". Kyiv .: DETUT [in Ukrainian].

10. Fastovets O.O. (2002) Rozvytok transportnoi systemy z naidavnishykh chasiv do pochatku KhKh st. yak chynnyk vynyknennia turystychnoi haluzi. [Development of the transport system from ancient times to the beginning of the twentieth century. as a factor in the emergence of the tourism industry] Kiev. : State Enterprise "National Tourist Organization" [in Ukrainian].

11. Ukravtodor. Derzhavne ahentstvo avtomobilnykh dorih Ukrainy [Ukravtodor. State Agency of Motor Roads of Ukraine] Road Bulletin of 2008. Access mode: www. ukravtodor.gov.ua. [in Ukrainian].

12. Yanovsky P.O. (2008) Passenger transportation. Kiev. : NAU, 2008. 469 c. [in Ukrainian].

13. Stratehiia rehionalnoho rozvytku Zaporizkoi oblasti na period do 2027 roku. [Strategy of regional development of Zaporozhye region for the period up to 2027]. Decision of the Zaporizhia Regional Council of 12.12.2019 № 134. 148 p. [in Ukrainian].

14. Yukhnovskaya Y.O. (2018) The current state of transport infrastructure of the tourism industry of Ukraine. Coll. Science. Dnipro Ave. nat. University of Iron. transp named after Academician V. Lazaryan, "Problems of Transport Economics" [in Ukrainian]. 